\title{
A Study on Human Capital Valuation and Management
}

\author{
K. V. N. Pallavi, A. K. Neeraja Rani \\ (Department of Management Studies, TRR College of Engineering, India) \\ (Department of MBA, Santhiram Engg., College, Nandyal, India)
}

\begin{abstract}
The days of exploitation of human resources on fiscal grounds and work load has wiped by the emergence of the era of Human capital. Many organisations recognised that there is a minor margin between "Best" and "The Best". It is possible for organisations to be called as "The Best" only if they could able to make parity between effective work from employees and efficiency of the same employees. It is that much difficult to maintain parity as many big organisations fail to continue in "The Best" position. It is fruitful only when Human is treated as Capital than a Resource/ expenditure. The difficulty starts then how to value Human capital, how to maintain it? The paper presents an insight in to the various methods of valuing Human Capital and how to maintain it successfully.
\end{abstract}

Keywords: Effectiveness, Efficiency, Human Capital, Human Capital Evaluation, Human Capital Management,

\section{Introduction}

Capital is cash/goods used to generate income by investing in a business. Organiastions invests human efforts to generate income. So Human is treated as capital. Generally accounting people consider non-human capital in financial statements and ignores human capital. The traditional accounting system is based on historical cost. In this method/ system of accounting only a few/ narrow range of intangibles are included in preparation of financial statements. Human capital is treated as inherent wealth of the organization. In this regard it is necessary to include INTELLECTUAL/ HUMAN capital in financial statements.

In this context the words of Mr. Narayanamurthy- Founder \& Chief Mentor Infosys Technologies Limited, about their work force is remembered:

"Human resources are the greatest assets of any company. You can raise tariffs or prevent MNCs from entering, but one can't stop the employees from leaving if they are dissatisfied."

The concept is developing faster in the growing global markets. A decade back the situation is quite reverse. Previously Humans are in search of good firms. But in today scenario firms are running behind competent human force. Nobel Prize winning economist Gary S. Becker(1992), coined the term "Human Capital".

He states that "The basic resource in any company is the people. The most successful companies and the most successful countries will be those that manage Human capital in the most effective and efficient manager."He linkedhuman capital to economic growth, from individual to national levels (e.g., per capita GDP).

Lucas (1988) made a clear link between human capital and economic growth. He argued for the combination of physical and human capital as drivers of economic development.

Intellectual capital/ Human capital consist of knowledge, skills, experience and abilities of employees.It is very difficult to value these elements. Even many calculations are made to value human capital all those attempts are only approximate values. There are various models to value human capital. They are discussed in brief as under.

\section{Human capital evaluation methods}

\section{II.1 Acquisition Cost Model}

This model is also known as "Historical Cost model". According to Brummet- "HR costs are current sacrifices for obtaining future benefits and are therefore to be treated as Asset." The method states to capitalize organisations expenditure on Recruitment, Selection, and T\&D of employees and treated as assets for Human Resource Accounting. This is the only method based on sound accounting principles and policies.

\section{II.2 Replacement Cost Model}

In this method the replacement cost of individuals and rebuilding cost of organisations are considered as it affects HR Asset value of both individuals and organization. 


\section{II.3 Opportunity Cost Model}

The method is engaged to compute the monetary value and allocation of people to promising activity.

\section{II.4 Behavioral Model}

The model traces out the variables which appreciates/ depreciates that result in achievement of end result variables. In short, it portraits a relationship between intervening variables of human factor with organization performance.

\section{II.5 Economic Model}

The model was propounded by Lev \& Schwartz. The model helps in valuating employees future contribution in today's worth. It is calculated through the formulae-

$: \mathbf{E}\left(\mathbf{V}_{\mathbf{Y}}\right)=\sum \mathbf{P}_{\mathbf{Y}}(\mathbf{t}+\mathbf{I}) \sum \mathbf{I}(\mathbf{T}) / \mathbf{t}-\mathbf{y}(\mathbf{I}+\mathbf{R})$

$\mathrm{E}\left(\mathrm{V}_{\mathrm{y}}\right)=$ expected value of a $\mathrm{Y}$ year old persons human capital.

$\mathrm{T}=$ persons retirement age.

$\mathrm{P}_{\mathrm{y}}(\mathrm{t})=$ probability of person leaving the organization.

$\mathrm{I}(\mathrm{t})=$ expected earnings of person in period I

$\mathrm{R}=$ discount rate.

In practical application of these models may have negatives and positives. Most of Indian companies like, Infosys, BHEL, SPIC, adopts Lev\&Schwartz model.

Creating transparency about the enterprises intellectual capital will enable it to manage its intangible resources better, increase staff confidence and motivation as well as imparting greater certainty to investors and other stake holders about its future earnings potential.

For the purpose Intellectual/ Human capital statements are prepared. These statements are about internal reporting. These statements are unique by considering the items which are useful in evaluating the future rather than only past. The firms are following a new methodology of considering both historical financial statements and INTELLECTUAL CAPITAL/HUMAN CAPITAL (IC/HC) statements for more transparency of an organization to create value. This even helps the organization in management of overall resources. HC statements will enable the organization to know value chain position and business model for value generation. To meet the increasing needs of Human Capital Management organisations are looking forward to HR business partners/ HR practitioners for direct and strategic support. A focus on companies opting support of HR practitioners.

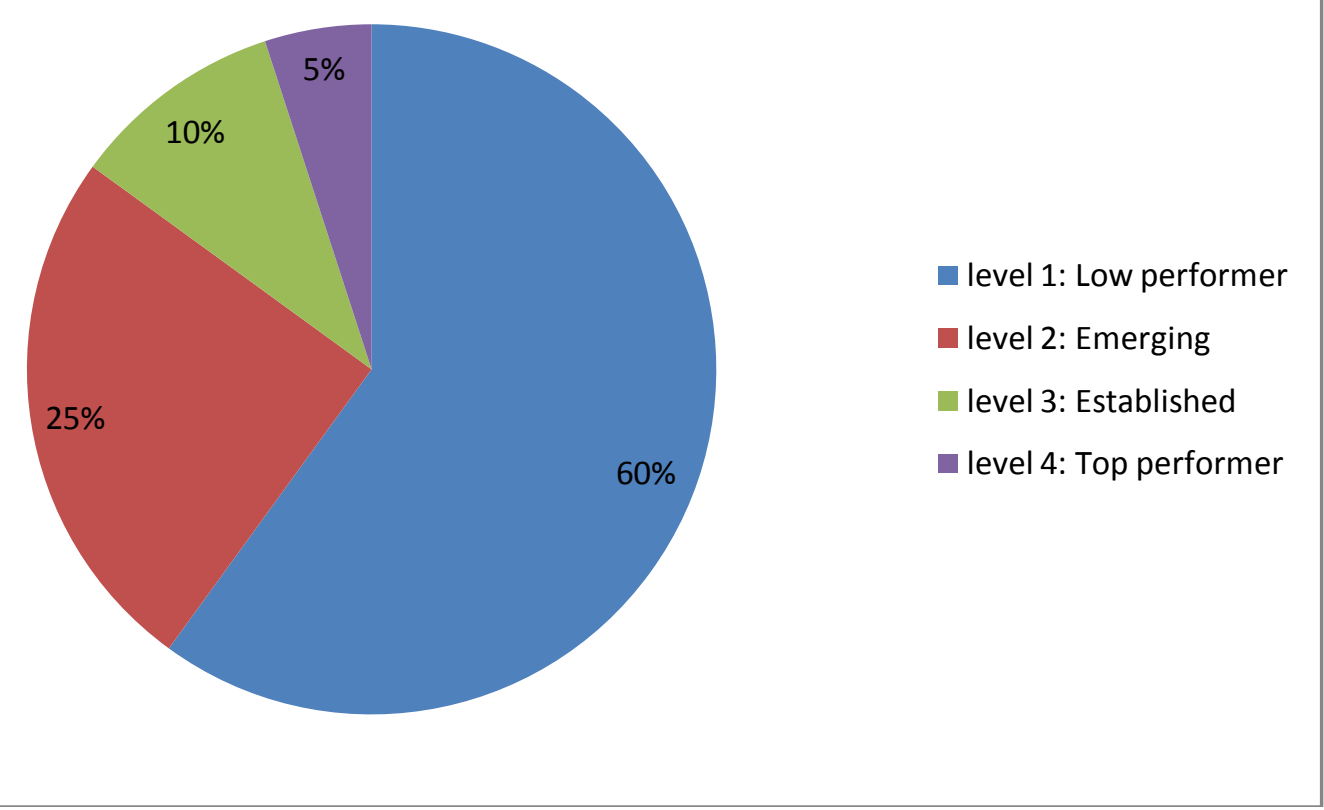

figure 1: \% of companies taking support 


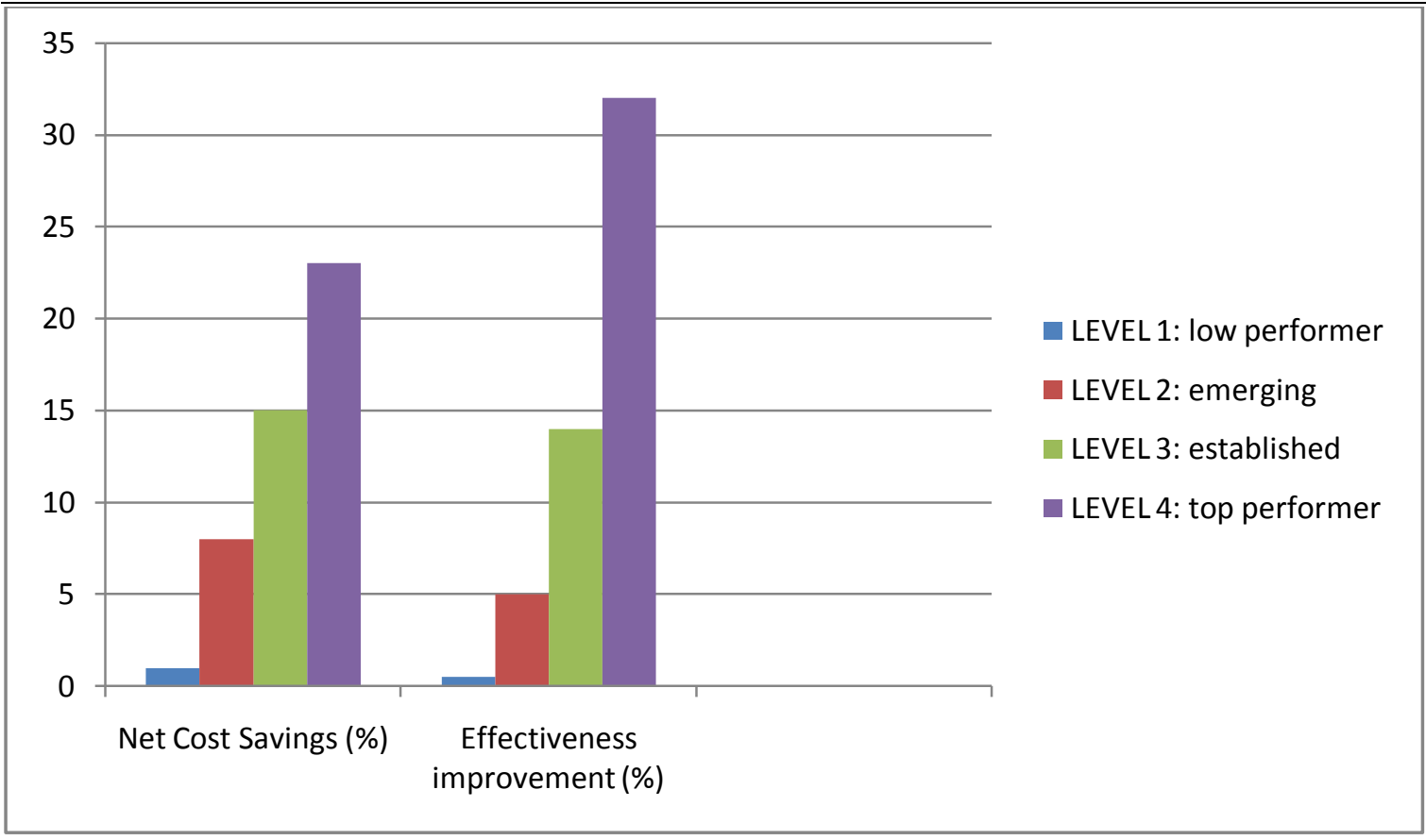

figure 2: rate of result

Most successful companies are those which are able to manage Human capital effectively and efficiently. A question of how to bring a balance between efficiency and effectiveness will arise for most of the emerging companies.

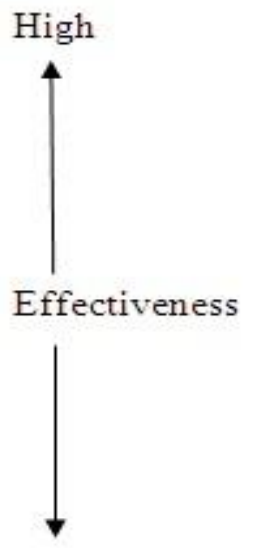

Low

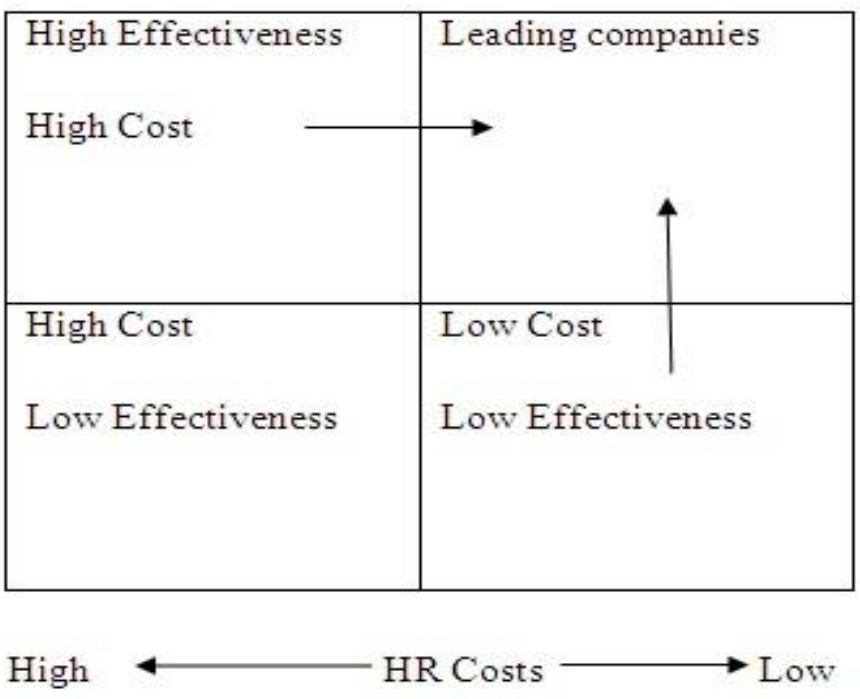

III. Measures for effectiveness

\subsection{Hard metrics}

Cycle times (hiring time), error rates, employee turnover.

\subsection{Soft metrics}

Employee engagement, customer satisfaction, alignment with corporate goals...etc.

4.1 Staffing levels

\section{Measures for efficiency}

Employees served per fulltime HR employee, fulltime HR employees per 1000 employees. 


\subsection{Costs}

HR cost per company employee.

Many of the best run human capital management organisations share some practices. They are:

Optimize process and transactional support.

Benchmark processes and performance.

Consolidate system.

Adopt shared services.

Invest in people and talent.

Align HR with overall business strategy and goals.

Focus on value, not effort.

\section{Suggestions and conclusion}

While valuating human resources we should consider three basic aspects, Utility, Supply, Demand. If valuation is done basing on these factors we can derive more accurate worth of the employee. Abundant supply of men generally decreases the worth of the resource. Like wise the worth of the resource is also dependent on Utility and Demand. There should be a distinction between the method of valuating non living assets and living assets (HUMAN). A non living asset's (machine's) value depreciates year by year where as value of living asset (Human) appreciates year by year as he attains experience. There is a ceiling or limitation for machine performance i.e., not more than standard capacity but there is no ceiling on the extent of performance of a living asset. So, all these aspects should be considered while valuating human capital. The method in which Human capital is valued should be rationale, fair, practical and reasonable. These valuable assets should be maintained and retained so as to enhance the relative worth of the organization.

\section{Websites:}

\section{REFERENCES}

[1] http://www.wilmar-international.com/investor/annualreports/2009/5_wilmar_AR09_HCM\&IT.pdf

[2] http://renegadehr.net/free-downloads/human-capital-handbook-2011.pdf

[3] http://www.infosys.com/investors/reports-filing/annual-report/annual/documents/AR-2011/ai_13.html

[4] $\quad$ http://www.nisg.org/home.php?page=humancapital.php

\section{Conference Reports/Journals/Surveys:}

[5] ASUG/SAP best practices survey (surveyed 250 companies)

[6] ASUG/SAP HR benchmarking program.

[7] Human Capital Metrics Conference: 2011, New York Marriott Downtown.

Books:

[8] Fitz-enz, Jac, The ROI of Human Capital. Amacom, 2000

[9] Jody Heymann with Magda Barrera- "Profit at the Bottom of the Ladder: Creating Value by Investing in Your Workforce": Harvard Business Press, 2010.

[10] Strategic Human Capital Management: Creating ... (Paperback) by Jon Ingham. 